\title{
DMT1: Which metals does it transport?
}

\author{
MICHAEL D GARRICK ${ }^{1,2}$, STEVEN T SINGLETON $^{1}$, FARIDA VARGAS $^{1}$, \\ H-C KUO* ${ }^{*}$, LIN ZHAO ${ }^{1}$, MARTIN KNÖPFEL ${ }^{3}$, TODD DAVIDSON ${ }^{4}$, MAX COSTA $^{4}$, \\ PRASAD PARADKAR ${ }^{5}$, JEROME A ROTH ${ }^{5}$ and LAURA M GARRICK ${ }^{1,6}$
}

\author{
Departments of ${ }^{1}$ Biochemistry, ${ }^{2}$ Pediatrics, ${ }^{5}$ Pharmacology \& Toxicology and ${ }^{6}$ Medicine, SUNY at Buffalo, \\ Buffalo, NY, USA \\ ${ }^{3}$ Tracechem, Berne, Switzerland \\ ${ }^{4}$ Nelson Institute of Environmental Medicine, New York University, Tuxedo, NY, USA
}

\begin{abstract}

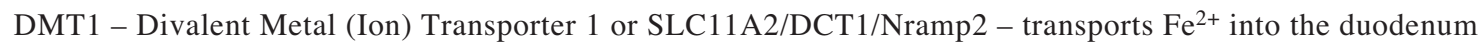
and out of the endosome during the transferrin cycle. DMT1 also is important in non-transferrin bound iron uptake. It plays similar roles in $\mathrm{Mn}^{2+}$ trafficking. Voltage clamping showed that six other metals evoked currents, but it is unclear if these metals are substrates for DMT1. This report summarizes progress on which metals DMT1 transports, focusing on results from the authors' labs. We recently cloned 1A/+IRE and 2/-IRE DMT1 isoforms to generate HEK293 cell lines that express them in a tetracycline-inducible fashion, then compared induced expression to uninduced expression and to endogenous DMT1 expression. Induced expression increases $\sim 50 \mathrm{x}$ over endogenous expression and $\sim 10 \mathrm{x}$ over uninduced levels. $\mathrm{Fe}^{2+}, \mathrm{Mn}^{2+}, \mathrm{Ni}^{2+}$ and $\mathrm{Cu}^{1+}$ or $\mathrm{Cu}^{2+}$ are transported. We also explored competition between metal ions using this system because incorporation essentially represents DMT1 transport and find this order for transport affinity:

$\mathrm{Mn}>$ ? $\mathrm{Cd}>$ ? $\mathrm{Fe}>\mathrm{Pb} \sim \mathrm{Co} \sim \mathrm{Ni}>\mathrm{Zn}$. The effects of decreased DMT1 also could be examined. The Belgrade rat has diminished DMT1 function and thus provides ways of testing. A series of DNA constructs that generate siRNAs specific for DMT1 or certain DMT1 isoforms yield another way to test DMT1-based transport.
\end{abstract}

Key terms: Metal ion transport; DCT1, Nramp2 or SLC11A2; expression assay: competition between metal ions

\section{INTRODUCTION}

DMT1 - Divalent Metal (Ion) Transporter 1 or SLC11A2 (OMIM's designation for solute carrier family 11 member 2) / DCT1 (Divalent Cation Transporter 1) / Nramp2 (Natural resistance associated macrophage protein 2) - definitely transports $\mathrm{Fe}^{2+}$ as part of both nutritional acquisition in the duodenum and exit from the endosome during the transferrin cycle (for reviews, see Garrick et al., 2003, and Garrick and Garrick, 2004). In addition to these two functions, DMT1 is likely to be important in non-transferrin bound iron uptake. The transporter probably plays similar roles in $\mathrm{Mn}^{2+}$ trafficking (for a review, see Roth and Garrick, 2003). Data from two-electrode voltage clamping studies (Gunshin et al.,
1997) showed that six other metals evoked currents, but it is not clear if these metals are substrates for DMT1.

Five of these metals are essential micronutrients that are harmful in oversupply: $\mathrm{Fe}, \mathrm{Mn}, \mathrm{Cu}, \mathrm{Zn}$ and $\mathrm{Co}$. Hence it is desirable to know DMT1's role in their homeostasis. The other three, $\mathrm{Ni}, \mathrm{Cd}$ and $\mathrm{Pb}$, are toxic without any known countervailing benefit, so it would be useful to know if uptake by DMT1 contributes to their effects. Also, as noted by Arredondo et al. (2003), ascorbate was present during the pioneering voltage clamping studies (Gunshin et al., 1997). It was necessary to have $\mathrm{Fe}^{2+}$ available, but some of the other cations studied also could be reduced.

This paper is a progress report on which metals DMT1 transports. It summarizes

\footnotetext{
* Current address, Departments of Biochemistry, Duke University, Durhman, NC, USA.

Corresponding author: Michael D. Garrick, Department of Biochemistry, SUNY, 140 Farber Hall, Buffalo, NY 14214, USA, Tel.: (1-716) 829-3926, Fax: (1-716) 829-2725, E-mail: mgarrick@ buffalo.edu
} 
data primarily from the authors' laboratories but also from many other groups and presents some previously unpublished data. At least four isoforms of DMT1 exist: 1A/+IRE, 1A/-IRE, 2/+IRE and 2/-IRE. In rats, all four share 543 central amino acid residues, but the $\mathrm{N}$ terminus for those encoded by mRNA that starts with exon $1 \mathrm{~A}$ has a 31 residue extension while the N-terminus starts in exon 2 for those encoded by mRNA that starts with exon 1B. C-terminal isoforms differ in the distal 18 or 25 amino acid residues. Because the mRNA isoforms that encode them differ by the presence or absence of an IRE (Iron Responsive Element) in the 3' UTR, the C-terminal isoforms are designated as \pm IRE.

One might imagine that different isoforms exhibit a preference for different metal ions, so it would be beneficial to have a means of examining this possibility. Increasing or decreasing the expression of DMT1 species presents a way to do so. We (Kuo et al., 2004) have cloned the $1 \mathrm{~A} /+\mathrm{IRE}$ and 2/-IRE forms into the Gateway system (Invitrogen) and created HEK293 cell lines (Garrick et al., 2005, unpublished data) that express them in a tetracycline (or doxycycline) inducible fashion. We have compared induced expression to uninduced expression and to endogenous DMT1 expression by control cells with the empty vector or just with the system that renders the cells inducible. Induced expression increases $\sim 50 \mathrm{x}$ over endogenous expression and $\sim 10 \mathrm{x}$ over uninduced levels. This series of cell lines allows us to investigate which metals can be transported by DMT1 .

Garrick et al. (2005, unpublished data) demonstrated that both isoforms transport $\mathrm{Fe}^{2+}$ and $\mathrm{Mn}^{2+}$. Chen et al. (2005) showed that the 2/-IRE species transports $\mathrm{Ni}^{2+}$; while Davidson, Vargas, Singleton, Garrick and Costa (unpublished data) have similar results for the $1 \mathrm{~A} /+\mathrm{IRE}$ species. Arredondo et al. (2005, unpublished data) examined $\mathrm{Cu}^{2+}$ and $\mathrm{Cu}^{1+}$ with HEK293 cells expressing the 2/-IRE form. Their data favor the hypotheses that $\mathrm{Cu}^{1+}$ is the ionic species taken up and that a reductase converts $\mathrm{Cu}^{2+}$ to that species before uptake; however, the data do not exclude the possibility that $\mathrm{Cu}^{2+}$ is a substrate for DMT1 with a lower affinity than $\mathrm{Cu}^{1+}$.

It is also easy to inquire into competition between metal ions using this system because incorporation essentially represents DMT1 transport without contributions from other transporters. Experimental results in this report come from this approach.

The ability to transport a metal ion in this assay is not an assurance that metal ion uptake normally relies on DMT1 because alternative pathways may be responsible for most transport. One can examine mutants like the Belgrade rat (Fleming et al., 1998) or the microcytic mouse (Fleming et al., 1997), both of which have a glycine to arginine mutation at the same residue. If one examines the protein isoforms starting in exon 2 , the residue number is 185 , therefore $\mathrm{G} 185 \mathrm{R}$ in the original reports. Awareness of $1 \mathrm{~A}$ isoforms now means that these should be called G216R in the rat or G215R in the mouse because there are 31 or 30 additional $\mathrm{N}$-terminal residues, respectively. In the discussion below, we summarize some recent results from studies of the Belgrade rat; we are unaware of any recent results in the mouse model after our prior review (Garrick et al., 2003).

We also have developed a series of DNA constructs (SECs) that generate siRNAs specific for DMT1 or certain DMT1 isoforms. Formally, this approach is similar to the antisense technology used by Arredondo et al. (2003) to indict DMT1 in transport of $\mathrm{Fe}^{2+}$ and $\mathrm{Cu}^{1+}$ in Caco-2 cells. Using siRNA producing SECs in the same inducible expression system, we have evaluated semiquantitatively the effect of the siRNAs on levels of specific DMT1 isoforms. After such preliminary data are accumulated, expression of the same siRNA constructs in cells where only endogenous expression of DMT1 occurs should be informative of which metals are actually transported.

\section{METHODS}

Most of the methods were described recently (Kuo et al., 2004). The competition assays relied on incubating HEK293 cells 
containing one of the following two constructs: mouse 2/-IRE or rat $1 \mathrm{~A} /+\mathrm{IRE}$ (each with a strong cytomegalovirus promoter under tetracycline control and a tetracycline response element) in the presence or absence of $50 \mathrm{nM}$ doxycycline for $24 \mathrm{hr}$. DMT1 expression (detected by uptake of $\mathrm{Fe}^{2+}$ or $\mathrm{Mn}^{2+}$ ) was $\sim 50 \mathrm{x}$ endogenous levels after such induction or $\sim 5 \mathrm{x}$ endogenous levels without such induction; hence uptake represented $\geq 98 \%$ or $\geq 80 \%$ DMT1 expression, respectively. When ${ }^{59} \mathrm{Fe}^{2+}$ was the substrate, its concentration was $100 \mathrm{nM}$; for ${ }^{54} \mathrm{Mn}^{2+}$ the concentration was $10 \mathrm{nM}$. Incubations were for 10 or $15 \mathrm{~min}$ in the presence of selected concentrations of competing metal ion, so that the initial velocity for uptake was measured. Statistical treatment of the data relied on linear regression analyses using Stata (StataCorp, College Station, TX). Additional details of the data reduction are described in the results to allow the reader to visualize how this was accomplished.

\section{RESULTS}

Competition between known substrates and candidates does not inform us as to whether the candidate is actually a substrate, but does reveal whether the candidate metal ion interacts with the transporter. An example is shown in figure 1 , where $\mathrm{Pb}^{2+}$ (from lead acetate) inhibits $\mathrm{Mn}^{2+}$ uptake. Although there were four conditions for the incubations, the results could be combined to calculate an $\mathrm{IC}_{50}$ (Inhibitor Concentration that yields $50 \%$ of control) of $7.3 \mu \mathrm{M}$. It was desirable to have a quicker and less subjective method to get this value, so we relied on the observation that there appears to be a linear relation for the three series of percents over the concentration range 1-100 $\mu \mathrm{M}$ and calculated the $\mathrm{IC}_{50}$ by linear regression analysis, obtaining an estimate of $8.5 \mu \mathrm{M}$ with $\mathrm{R}^{2}=0.88$. Similar calculations for an analysis of $\mathrm{FeSO}_{4}$ inhibition of $\mathrm{Mn}^{2+}$ uptake gave an estimate of $2.0 \mu \mathrm{M}$ for that $\mathrm{IC}_{50}$ with $\mathrm{R}^{2}=0.90$ while the graphical estimate was $2.1 \mu \mathrm{M}$ for the $\mathrm{IC}_{50}$. Linear regression analysis over the log/linear range therefore was applied to a series of analyses like figure 1 to get the data shown in table 1 . The $\mathrm{R}^{2}$ ranged from 0.77 to 0.95 indicating that $\sim 77$ to $\sim 95 \%$ of the variation in the scatter is due to the linear relationship.

The data in table 1 indicate that there is generally satisfactory agreement between separate experiments when the same uptake is blocked by the same inhibitor, but there is a discrepancy when the uptake of $\mathrm{Mn}$ is compared to that for $\mathrm{Fe}$. For examples, $\mathrm{CoCl}_{2}$ has similar $\mathrm{IC}_{50} \mathrm{~s}$ of 87.6 and 80.2 when blocking ${ }^{59} \mathrm{Fe}^{2+}$ uptake; but the $\mathrm{IC}_{50} \mathrm{~S}$

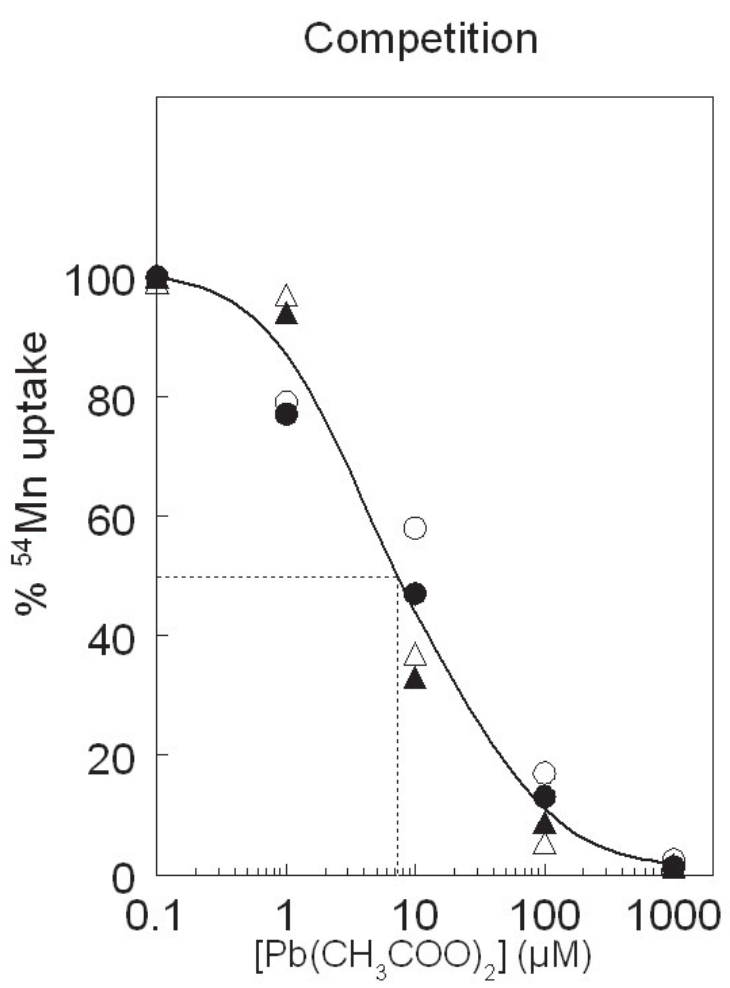

Figure 1. Inhibition of $\mathrm{Mn}$ uptake by $\mathrm{Pb}$. Cells were incubated with ${ }^{54} \mathrm{Mn}^{2+}$ and selected concentrations of lead acetate $\left[\mathrm{Pb}\left(\mathrm{CH}_{3} \mathrm{COO}\right)_{2}\right]$ with $(\boldsymbol{\Delta} \Delta)$ and without $(\boldsymbol{O})$ doxycycline for the 2/-IRE $(\boldsymbol{\Delta} \mathbf{O})$ and $1 \mathrm{~A} /+\operatorname{IRE}(\Delta \mathrm{O})$ lines. Although induced incorporation in the presence of doxycycline was $\sim 10 \mathrm{x}$ that without induction, the incubations without $\mathrm{Pb}$ were treated as $100 \%$ uptake for each series to allow comparison. We fitted the concentration response with a single cubic spline because the 4 series of competitions were indistinguishable. Dropping a line from the $50 \%$ level yielded an $\mathrm{IC}_{50}$ at $7.3 \mu \mathrm{M}$. 
TABLE 1

Estimated $\mathrm{IC}_{50}$ for selected metal ions, inhibiting DMT1 metal ion uptake

\begin{tabular}{|c|c|c|c|}
\hline $\mathrm{IC}_{50}$ by regression $(\mu \mathrm{M})^{1}$ & $\mathrm{IC}_{50}$ graphical $(\mu \mathrm{M})^{2}$ & $\mathrm{Me}^{2+}$ taken up & Inhibitor \\
\hline 2.0 & 2.1 & ${ }^{54} \mathrm{Mn}^{2+}$ & $\mathrm{FeSO}_{4}$ \\
\hline 87.6 & & ${ }^{59} \mathrm{Fe}^{2+}$ & $\mathrm{CoCl}_{2}$ \\
\hline 80.2 & & ${ }^{59} \mathrm{Fe}^{2+}$ & $\mathrm{CoCl}_{2}$ \\
\hline 8.3 & & ${ }^{54} \mathrm{Mn}^{2+}$ & $\mathrm{CoCl}_{2}$ \\
\hline 6.4 & & ${ }^{54} \mathrm{Mn}^{2+}$ & $\mathrm{CoCl}_{2}$ \\
\hline 18.4 & & ${ }^{59} \mathrm{Fe}^{2+}$ & $\mathrm{CdCl}_{2}$ \\
\hline 21.3 & & ${ }^{59} \mathrm{Fe}^{2+}$ & $\mathrm{CdCl}_{2}$ \\
\hline 1.8 & & ${ }^{54} \mathrm{Mn}^{2+}$ & $\mathrm{CdCl}_{2}$ \\
\hline 0.5 & & ${ }^{54} \mathrm{Mn}^{2+}$ & $\mathrm{CdCl}_{2}$ \\
\hline 264.6 & & ${ }^{59} \mathrm{Fe}^{2+}$ & $\mathrm{ZnSO}_{4}$ \\
\hline 180.3 & & ${ }^{59} \mathrm{Fe}^{2+}$ & $\mathrm{ZnSO}_{4}$ \\
\hline 40.9 & & ${ }^{54} \mathrm{Mn}^{2+}$ & $\mathrm{ZnSO}_{4}$ \\
\hline 160.8 & & ${ }^{54} \mathrm{Mn}^{2+}$ & $\mathrm{ZnSO}_{4}$ \\
\hline 52.6 & & ${ }^{54} \mathrm{Mn}^{2+}$ & $\mathrm{ZnSO}_{4}$ \\
\hline 4.6 & & ${ }^{54} \mathrm{Mn}^{2+}$ & $\mathrm{Pb}\left(\mathrm{C}_{2} \mathrm{H}_{3} \mathrm{O}_{2}\right)_{2}$ \\
\hline 8.5 & 7.3 & ${ }^{54} \mathrm{Mn}^{2+}$ & $\mathrm{Pb}\left(\mathrm{C}_{2} \mathrm{H}_{3} \mathrm{O}_{2}\right)_{2}$ \\
\hline 10.8 & & ${ }^{54} \mathrm{Mn}^{2+}$ & $\mathrm{NiCl}_{2}$ \\
\hline 5.5 & & ${ }^{54} \mathrm{Mn}^{2+}$ & $\mathrm{NiCl}_{2}$ \\
\hline
\end{tabular}

${ }^{1}$ Each value estimated by linear regression analysis from three or more sets of points representing combined analyses on 2/-IRE and 1A/+IRE constructs with and without doxycycline as shown in figure 1 and described in the text. Combination of the points for linear regression analysis was justified by the lack of difference between constructs or for data with and without doxycycline. All represented $80 \%$ to $98 \%$ expression of the construct used because endogenous expression was $20 \%$ of that without doxycycline and $2 \%$ of that with doxycycline. Where there are pairs of values, each represents an independent experiment analyzed in this fashion.

${ }^{2}$ Estimated graphically as shown in figure 1 .

of 8.3 and 6.4 when blocking ${ }^{54} \mathrm{Mn}^{2+}$ uptake, although similar to each other, are more than $10 x$ less. $\mathrm{CdCl}_{2}$ exhibits similar behavior but at a lower concentration. We consider the likely explanation in the discussion section that follows. The only exception to this observation is that $\mathrm{ZnSO}_{4}$ gives less reproducibility and that there is not so great a difference between its ability to block Fe and Mn uptake. These issues could relate to its being the least effective inhibitor. Although a number of metal ions remain to be studied, these data and data that show the $\mathrm{K}_{\mathrm{m}}$ to be $\sim 1 \mu \mathrm{M}$ for $\mathrm{Mn}^{2+}$ and $\sim 3 \mu \mathrm{M}$ for $\mathrm{Fe}^{2+}$ (Garrick et al., 2005, unpublished data) permit the following rankings for transport affinity of the metal ions: $\mathrm{Mn}^{2+}>$ ? $\mathrm{Cd}^{2+}>$ ? $\mathrm{Fe}^{2+}>\mathrm{Pb}^{2+} \sim \mathrm{Co}^{2+} \sim \mathrm{Ni}^{2+}>\mathrm{Zn}^{2+}$.
The data in table 1 favor the placement of $\mathrm{Cd}^{2+}>\mathrm{Fe}^{2+}$, but the question mark (?) is attached because the uncertainty in the $\mathrm{IC}_{50}$ measurements does not permit a stronger conclusion.

\section{DISCUSSION}

\section{Competition}

It was initially puzzling that the $\mathrm{IC}_{50}$ for $\mathrm{CdCl}_{2}$ was lower when it competed with $\mathrm{Mn}$ than when it competed with Fe and that a similar relationship occurred for $\mathrm{CoCl}_{2}$. One expected the $\mathrm{K}_{\mathrm{i}}$ for DMT1 to be the same with $\mathrm{CdCl}_{2}$, independent of the substrate transported. An $\mathrm{IC}_{50}$ is not, 
however, a $\mathrm{K}_{\mathrm{i}}$. Their relationship was defined by Cheng and Prusoff (1973) as shown below in Equation 1.

(1) $\mathrm{K}_{\mathrm{i}}=\frac{\mathrm{IC}_{50}}{1+[\mathrm{L}] / \mathrm{K}_{\mathrm{D}}} \quad$ where $[\mathrm{L}]$ is the substrate (ligand) concentration and $\mathrm{K}_{\mathrm{D}}$ is the dissociation constant.

The arrangement in Equation 2 below aids us in viewing the influence of these variables.

$$
\text { (2) } \mathrm{IC}_{50}=\frac{\mathrm{K}_{\mathrm{i}} \cdot\left(\mathrm{K}_{\mathrm{D}}+[\mathrm{L}]\right)}{\mathrm{K}_{\mathrm{D}}}
$$

Although the $\mathrm{K}_{\mathrm{D}} \mathrm{S}$ for $\mathrm{Fe}$ and $\mathrm{Mn}$ are unknown, the $\mathrm{K}_{\mathrm{m}} \mathrm{s}$ are $\sim 3$ and $\sim 1 \mu \mathrm{M}$ (Garrick et al., 2005, unpublished data). If the ratios of the $\mathrm{K}_{\mathrm{D}} \mathrm{S}$ is similar, and the $\mathrm{K}_{\mathrm{D}}$ for each is $<[L]$, then the ratio of the substrate concentrations will affect the relative $\mathrm{IC}_{50}$ values. The $\sim 10 \mathrm{x}$ difference that we see reflects the ratio $[\mathrm{Fe}] /[\mathrm{Mn}]$ (= 10) closely, so we suspect that the weights of [L] and different $\mathrm{K}_{\mathrm{D}} \mathrm{S}$ account for our observation.

\section{The Belgrade (b/b) rat}

Because G185R mutated DMT1 is clearly defective, preparations from $b / b$ rats provide an opportunity to learn more about the role of the transporter. Knöpfel et al. (2005b) used vesicles prepared from duodenal brush border membranes (BBM) to investigate how a calcein-based fluorescence quenching assay performed when the vesicles' DMT1 was defective. The assay had been developed earlier but used only on normal rabbit BBM. The results indicated that defective $b / b$ DMT1 in $\mathrm{BBM}$ failed to transport $\mathrm{Ni}^{2+}, \mathrm{Fe}^{2+}$ and $\mathrm{Mn}^{2+}$, while BBM from $+/ b$ rats transported all three divalent metal ions successfully. The data therefore provided confirmation that $b / b$ DMT1 is defective and evidence that normal DMT1 transports the three metal ions. Their observation that vesicles from $+/ b$ basolateral membranes (BLM) also had vigorous transport, while those from $b / b$ BLM did not, is evidence that DMT1 also may serve functions in enterocytes at other locations than the apical surface.
$\mathrm{Ni}$ transport into $+/ b$ vesicles was considerably slower than $\mathrm{Mn}$ or $\mathrm{Fe}$ (Knöpfel et al., 2005b). Davidson, Vargas, Singleton, Garrick and Costa (unpublished data) also observe that $\mathrm{Ni}$ uptake in HEK293 cells over-expressing DMT1 is slower than Mn or Fe uptake.

In the earlier paper, $\mathrm{Zn}^{2+}$ also caused quenching in calcein-loaded rabbit BBM (Knöpfel et al. 2000). Because $\mathrm{Zn}^{2+}$ itself does not quench calcein fluorescence, the authors proposed that proton cotransport was responsible and provided evidence that vesicle $\mathrm{pH}$ is actually affected. The alternative that $\mathrm{Zn}^{2+}$ gates proton transport and is not actually transported remains to be disproved, however. Nelson (1999; Sacher et al., 2001) initially favored that possibility, but currently supports Zn transport by DMT1 (Nevo and Nelson, 2004).

Very recently, Knöpfel et al. (2005a) employed $b / b$ and $+/ b$ BBMV to show that $\mathrm{Cu}$ also is transported by DMT1, but only when the DMT1 is not defective. They examined both $\mathrm{Cu}^{2+}$ and $\mathrm{Cu}^{1+}$ as substrate. Although they saw activity with each, they argue that the former is the actual substrate. Interestingly, as mentioned in the introduction, Arredondo et al. (2005, unpublished data), assayed for uptake of $\mathrm{Cu}^{2+}$ and $\mathrm{Cu}^{1+}$ during induced DMT1 expression and seeing activity with both, interpreted the results as favoring the latter as the actual substrate. Resolving this dispute is beyond the scope of this discussion, but because $\mathrm{Cu}^{2+}$ can be reduced by a reductase that might be dcytb (Knöpfel and Solioz, 2002), it will take exceptionally well-controlled experiments to provide a final answer to whether one or both forms of $\mathrm{Cu}$ is a substrate for DMT1.

Knöpfel et al. (2005a) also took advantage of the absence of DMT1 activity in $b / b$ preparations in two ways. They demonstrated that $\mathrm{Co}^{2+}$ is a substrate of DMT1 and showed that vesicles from $b / b$ BBM had another transporter for $\mathrm{Cu}$ that depended on ATP and had a higher transport affinity. $\mathrm{Ni}$ and $\mathrm{Co}$ also exhibited ATP-driven transport. Forbes and Gros (2003) have also shown by calcein quenching that DMT1 transports Co and 
Mn in cells expressing high levels of DMT1.

\section{Current status}

The issue of which metals DMT1 transports remains a topic for intensive investigation. This report suggests the following order for DMT1 transport affinities: $\mathrm{Mn}>$ ? $\mathrm{Cd}>$ ? $\mathrm{Fe}>\mathrm{Pb} \sim \mathrm{Co} \sim \mathrm{Ni}>\mathrm{Zn}$ with some uncertainty on where to place $\mathrm{Cu}$. One should keep in mind, however, that binding to DMT1 is only one of many factors that will determine the ultimate physiological and toxicological effects. Other metal-binding proteins and targets will play downstream roles and each may have alternative transporters. Keeping these caveats in mind, some conclusions are outlined below.

$\mathrm{Fe}^{2+}$ is definitely a substrate in which there is no question that DMT1's role is physiologically significant. One would like to know what other pathways for iron entry into cells and exit from endosomes exist, their relative contributions and what species of iron they involve. The same conclusion applies to $\mathrm{Mn}^{2+}$, but even less is known about alternative pathways and their relative impact.

DMT1 clearly can transport $\mathrm{Cu}$, but whether the ionic form is cuprous or cupric is less certain. Other transporters clearly exist for this metal's ion(s), and the physiological role for DMT1 is still uncertain. Co is clearly a substrate, but the physiological significance of this observation needs additional elaboration; Zn may be a substrate but also deserves more study. There are clearly alternative transporters for $\mathrm{Zn}$ which begs the question of whether DMT1 plays much of a role physiologically, given the high concentration of $\mathrm{Zn}^{2+}$ needed for the $\mathrm{IC}_{50}$ and the total serum concentration of $\mathrm{Zn}$ of $\sim 12-17 \mu \mathrm{M}$.

DMT1-mediated uptake of $\mathrm{Ni}$ is probably toxicologically relevant, but here too, more data are desirable. Cd binds tightly to DMT1 and earlier studies (reviewed in Garrick et al., 2003) leave little doubt that DMT1 actually transports this metal. Such transport also is probably relevant toxicologically. $\mathrm{Pb}$ may be transported by DMT1 as well (also reviewed in Garrick et al., 2003), but there are questions about whether DMT1 transport of $\mathrm{Pb}$ is relevant toxicologically. Finally, we should keep in mind that the list of eight metals is almost certainly incomplete; other metal ions should be tested and even negative results should be reported.

\section{ACKNOWLEDGMENTS}

The research results reported or described here received support from NIH grants \# DK59794 (LMG), ES11127 (JAR), ES00260 (MC), ES10344 (MC), 808 T32-ES07324 (MC) and a grant FP-91641801-0 from the Environmental Protection Agency (TD) plus a grant from the National Research Initiative of the USDA Cooperative State Research, Education and Extension Service, 200135200-10723 (MDG).

\section{REFERENCES}

ARREDONDO M, MUÑOZ P, MURA CV, NÚÑEZ MT (2003) DMT1, a physiologically relevant apical $\mathrm{Cu}^{1+}$ transporter of intestinal cells. Am. J. Physiol. Cell Physiol. 284: C1525-C1530

CHEN H, DAVIDSON T, SINGLETON S, GARRICK MD, COSTA M (2005) Nickel decreases cellular iron level and converts cytosolic aconitase to iron regulated protein 1. Toxicol. Appl. Pharmacol. 206: 275-287

CHENG Y, PRUSOFF WH (1973) Relationship between the inhibition constant $(\mathrm{Ki})$ and the concentration of inhibitor which causes 50 per cent inhibition (I50) of an enzymatic reaction. Biochem. Pharmacol. 22: 3099-3108

FLEMING MD, TRENOR CI, SU MA, FOERNZLER D, BEIER DR, DIETRICH WF, ANDREWS NC (1997) Microcytic anaemia mice have a mutation in Nramp2, a candidate iron transporter gene. Nature Genet. 16: 383386

FLEMING MD, ROMANO MA, SU MA, GARRICK LM, GARRICK MD, ANDREWS NC (1998) Nramp2 is mutated in the anemic Belgrade $(b)$ rat: Evidence of a role for Nramp2 in endosomal iron transport. Proc. Natl. Acad. Sci. USA 95: 1148-1153

FORBES JR, GROS P (2003) Iron, manganese, and cobalt transport by Nramp1 (Slc11a1) and Nramp2 (Slc11a2) expressed at the plasma membrane. Blood 102: 18841892

GARRICK MD, DOLAN KG, GHIO A, HORBINSKI C, HIGGINS D, PORUBCIN M, MOORE EG, HAINSWORTH LN, UMBREIT JN, CONRAD ME, FENG L, LIS A, ROTH JE, SINGLETON S, GARRICK LM (2003) DMT1 (Divalent Metal Transporter 1): A mammalian transporter for multiple metals. BioMetals 16: 41-54

GARRICK MD, GARRICK LM (2004) Divalent metal transporter DMT1 (SLC11A2). In: BROER S, WAGNER C (eds) Membrane Transporter Diseases. Dordrecht: Kluwer, pp: 107-122 
GARRICK MD, KUO H, VARGAS F, SINGLETON ST, ZHAO L, SMITH JJ, PARADKAR P, ROTH JA, GARRICK LM (2005) Comparison of mammalian cell lines expressing distinct isoforms of divalent metal transporter 1 in a tetracycline-regulated fashion. J. Biol. Chem. Ms submitted

GUNSHIN H, MACKENZIE B, BERGER UV, GUNSHIN Y, ROMERO MF, BORON WF, NUSSBERGER S, GOLLAN JL, HEDIGER MA (1997) Cloning and characterization of a mammalian proton-coupled metalion transporter. Nature (London) 388: 482-488

KNÖPFEL M, SCHULTHESS G, FUNK F, HAUSER H (2000) Characterization of an integral protein of the brush border membrane mediating the transport of divalent metal ions. Biophys. J. 79: 874-884

KNÖPFEL M, SOLIOZ M (2002) Characterization of a cytochrome b558 ferric/cupric reductase from rabbit duodenal brush border membranes. Biochem. Biophys. Res. Commun. 291: 220-225

KNÖPFEL M, SMITH C, SOLIOZ M (2005a) ATP-driven copper transport across the intestinal brush border membrane. Biochem. Biophys. Res. Commun. 330: 645-652
KNÖPFEL M, ZHAO L, GARRICK MD (2005b) Transport of divalent transition-metal ions is lost in smallintestinal tissues of $b / b$ Belgrade rats. Biochem. 44: 3454-3465

KUO HC, SMITH JJ, LIS A, ZHAO L, GONSIOREK EA, ZHOU X, HIGGINS DM, ROTH JA, GARRICK MD, GARRICK LM (2004) Computer-identified nuclear localization signal in exon $1 \mathrm{~A}$ of the transporter DMT1 is essentially ineffective in nuclear targeting. J. Neurosci. Res. 76: 497-511

NELSON N (1999) Metal ion transporters and homeostasis. EMBO J. 18: 4361-4371

NEVO Y, NELSON N (2004) The mutation F227I increases the coupling of metal ion transport in DCT1. J. Biol. Chem. 279: 53056-53061

ROTH JA, GARRICK MD (2003) Iron interactions and other biological reactions mediating the physiological and toxic actions of manganese. Biochem Pharmacol 66: $1-13$

SACHER A, COHEN A., NELSON N (2001) Properties of the Mammalian and Yeast Metal-Ion transporters DCT1 and Smf1p Expressed in Xenopus laevis oocytes. J. Exp. Biol. 204: 1053-1061 